\title{
DO “FEMINISMO POPULAR” AO “FEMINISMO PERIFÉRICO”: MUDANÇAS ESTRUTURAIS EM CONTRAPÚBLICOS DA ZONA LESTE DE SÃO PAULO*
}

\author{
From "popular feminism" to "peripheral feminism": \\ structural transformations in São Paulo's East Side's counterpublics
}

Jonas Medeiros'

\begin{abstract}
Resumo
0 tema deste artigo é o subcampo feminista da Zona Leste da cidade de São Paulo. Por meio de entrevistas, observação participante e análise de redes sociais digitais foram identificados dois momentos históricos: [i] o "feminismo popular" (associações que atendiam mulheres em situação de violência) surgido nos anos 1980 e 90; e [ii] a emergência simultânea, na década de 2010, da Rede Leste de Enfrentamento à Violência (convênios da assistência social municipal) e do "feminismo periférico" (coletivos com práticas artístico-culturais). Entre estes momentos foram detectadas descontinuidades quando consideradas as suas matrizes discursivas às quais foram nomeadas de mudanças estruturais nos contrapúblicos deste território: (1) fluxos verticais em direção ao Estado tiveram um efeito paradoxal ao abrir espaço para práticas menos institucionalizadas; (2) contrapúblicos digitais e a autocomunicação de massa substituíram uma rede articuladora de ONGs feministas com sedes fora da Zona Leste; (3) o Partido dos Trabalhadores deixou de ser central frente a coletivos apartidários; (4) a pluralização religiosa e a intervenção conservadora do Vaticano anularam as CEBs como contrapúblicos enraizados no cotidiano das periferias urbanas; e (5) sendo as matrizes discursivas do "feminismo periférico" contrapúblicos negros, isto explica a centralidade para este novo ativismo da questão racial e de um código oposicional antirracista.
\end{abstract}

Palavras-chave: campo feminista; esfera pública; institucionalização; movimentos sociais; periferias urbanas.

\begin{abstract}
The theme of this article is the feminist subfield of São Paulo's East Side. Two historical moments were identified using interviews, participant observation and social media analysis: [i] the "popular feminism" that emerged in the 1980s and 1990s (community centers that assisted women in situations of violence); [ii] the simultaneous emergence in the 2010s of the East Network to Combat Violence (city's social welfare agreements with NGO's) and the "peripheral feminism" (groups focusing in cultural and artistic initiatives). Discontinuities were detected among these moments when considering their discursive matrixes, meaning structural changes in this territory's counterpublics: (1) vertical flows towards the State had a paradoxical effect by enabling less institutionalized practices; (2) digital counterpublics and mass self-communication replaced a network of feminist NGOs with headquarters outside the East Side; (3) the Workers' Party was no longer central to non-partisan groups; (4) religious pluralization and conservative Vatican intervention annulled the Basic Ecclesial Communities as counterpublics rooted in
\end{abstract}

1 Doutor em Educação pela Universidade Estadual de Campinas (Unicamp), realiza pós-doutorado no Centro Brasileiro de Análise e Planejamento (Cebrap). E-mail: jonas.msm@gmail.com Cidade: São Paulo. 
the urban outskirts' everyday life; and (5) since the peripheral feminism's discursive matrixes are mainly black counterpublics, this led to the centrality of race and of an anti-racist oppositional code to this new activism.

Keywords: Feminist Field; Institutionalization; Public Sphere; Social Movements; Urban Outskirts.

\section{Introdução}

Este artigo apresenta resultados de pesquisa de doutorado (MEDEIROS, 2017), que se insere na sociologia dos movimentos sociais e da esfera pública, tendo como objeto o associativismo de mulheres nas periferias da Zona Leste da cidade de São Paulo. O objetivo da primeira etapa de minha pesquisa de campo foi o mapeamento das associações, organizações, movimentos e coletivos que lutam pelos direitos das mulheres nesta região da capital. O recorte conceitual para construir meu problema de pesquisa foi a categoria de matrizes discursivas, compreendida como as esferas públicas que permitem a reelaboração simbólica da vida cotidiana e a emergência de ações coletivas contra situações sociais que passam a ser avaliadas como injustas. $\mathrm{Na}$ totalidade da investigação foram utilizados os seguintes procedimentos empíricos ${ }^{2}: 40$ entrevistas semiestruturadas com integrantes de 36 diferentes iniciativas da sociedade civil; observação participante em eventos organizados por coletivos formados por mulheres jovens; análise de rede das páginas de Facebook seguidas pelas integrantes destes mesmos coletivos; e análise de conteúdo de uma campanha virtual feminista na mesma rede social. Um dos principais resultados que alcancei foi a constatação da complexidade histórica do associativismo de mulheres neste território e a identificação, no seu interior, de três diferentes tipos de organizações: (1) a rede de associações de mulheres que eu chamei de "feminismo popular"; (2) as casas conveniadas que integram a Rede Leste de Enfrentamento à Violência; e (3) a rede de coletivos que algumas de suas integrantes chamam de "feminismo periférico".

O "feminismo popular" consiste em associações e movimentos de mulheres fundados nas décadas de 1980-90, por mulheres nascidas nas décadas de 1940-60 a partir de suas experiências nas Comunidades Eclesiais de Base (CEB's), em movimentos sociais populares urbanos (lutas por

\footnotetext{
2 Sobre o impacto na coleta de dados dos limites e potencialidades da minha situação social (pesquisador homem branco de classe média) em interação com as posicionalidades de minhas interlocutoras (mulheres periféricas, a maioria delas negras), cf. a Introdução de minha tese (MEDEIROS, 2017, p. 2337) e sua versão modificada e ampliada em artigo (MEDEIROS, 2019).
} 
Do "feminismo popular" ao "feminismo periférico" | Jonas Medeiros

moradia, saúde e creche), com filiação ao Partido dos Trabalhadores (PT) em algum momento de sua trajetória política e no contato com a assessoria de Organizações Não-Governamentais (ONGs) feministas, e cuja principal prática foi o atendimento jurídico e psicológico de mulheres em situação de violência. ${ }^{3}$

Já os Centros de Defesa e Convivência da Mulher (CDCMs) são uma modalidade relativamente nova (com origem nos anos 2000 mas com seu fortalecimento na década seguinte) de atuação no campo dos direitos das mulheres: serviços conveniados com a Secretaria Municipal de Assistência e Desenvolvimento Social (SMADS) que emergem a partir do "feminismo popular". Há um formato padrão pré-determinado pela Secretaria (há, por exemplo, sempre uma gerente - ou coordenadora -, uma assistente social, uma psicóloga e uma advogada) e as entidades conveniadas devem vencer um processo de audiência pública. Estas casas conveniadas têm uma atuação híbrida (enquanto sociedade civil e braço do Estado) além de se organizarem sob a forma de uma rede - a Rede Leste de Enfrentamento à Violência. ${ }^{4}$

E, por fim, o "feminismo periférico" é constituído por coletivos que, na maioria das vezes, se autocompreendem como feministas e que surgem a partir do ano de 2010, por iniciativa de mulheres jovens, nascidas nas décadas de 1980-90, sem estruturação político-partidária e a partir do encontro entre movimentos culturais periféricos e debates sobre feminismo nas redes sociais digitais. Suas principais práticas são de caráter artístico-cultural. ${ }^{5}$

TABELA 1 - ORGANIZAÇÕES DO SUBCAMPO FEMINISTA NA ZONA LESTE DE SÃO PAULO (LISTA NÃO EXAUSTIVA)

\begin{tabular}{|l|c|c|c|}
\hline NOME & FUNDAÇÃO & DISTRITO & TIPO DA ORGANIZAÇ̃̃O \\
\hline Associação de Mulheres da Zona Leste (Amzol) & 1987 & Itaim Paulista & associação "feminista popular" \\
\hline Casa Anastácia & 2012 & Cidade Tiradentes & CDCM/Rede Leste \\
\hline Casa Cidinha Kopcak & 2002 & São Mateus & CDCM/Rede Leste \\
\hline Casa da Mulher Lilith & 1989 & Vila Prudente & associação "feminista popular" \\
\hline Casa Viviane dos Santos & 2004 & Guaianases & CDCM/Rede Leste \\
\hline Casa Zizi & 2012 & Vila Prudente & CDCM/Rede Leste \\
\hline Coletivo de Mulheres de São Mateus & 1989 & São Mateus & associação "feminista popular" \\
\hline Fayola Odara & 2013 & Guaianases & coletivo "feminista periférico" \\
\hline Grupo Cultural Dandara & 1990 & José Bonifácio & associação "feminista popular" \\
\hline Juntas na Luta & 2012 & Guaianases & coletivo "feminista periférico" \\
\hline M.A.N.A. Crew & 2015 & Cidade Tiradentes & coletivo "feminista periférico" \\
\hline
\end{tabular}

\footnotetext{
3 Foram entrevistadas seis associações: Associação de Mulheres da Zona Leste (Amzol); Casa da Mulher Lilith; Coletivo de Mulheres de São Mateus; Espaço Lilás do Oriashé; Grupo Cultural Dandara; e Movimento de Mulheres de São Miguel.

${ }_{4}^{4}$ Foram entrevistados seis dos sete CDCMs da Zona Leste: Casa Anastácia; Casa Cidinha Kopcak; Casa Zizi; Maria da Penha; MulherAção; e Naná Serafim (faltando apenas a Casa Viviane dos Santos).

5 Foram entrevistados sete coletivos: Fayola Odara; Juntas na Luta; M.A.N.A. Crew; Mulheres de Orí; Mulheriu Clã; Semente Crioula; e Ser Vi Elas.
} 
Do "feminismo popular" ao "feminismo periférico" | Jonas Medeiros

\begin{tabular}{l|c|c|c|}
\hline Maria da Penha & 2012 & Itaquera & CDCM/Rede Leste \\
\hline Movimento de Mulheres de São Miguel & 1993 & São Miguel & associação "feminista popular" \\
\hline MulherAção & 2012 & Guaianases & CDCM/Rede Leste \\
\hline Mulheres de Orí & 2014 & Cidade Tiradentes & coletivo "feminista periférico" \\
\hline Mulheriu Clã & 2013 & Cidade Tiradentes & coletivo "feminista periférico" \\
\hline Naná Serafim & 2013 & Itaim Paulista & CDCM/Rede Leste \\
\hline Oriashé/Espaço Lilás & $1988 / 2003$ & Bixiga/Cidade Tiradentes & associação "feminista popular" \\
\hline Semente Crioula & 2014 & Guaianases & coletivo "feminista periférico" \\
\hline Ser Vi Elas & 2015 & São Miguel & coletivo "feminista periférico" \\
\hline
\end{tabular}

Fonte: elaboração própria a partir de entrevistas

Este artigo está estruturado da seguinte maneira. A primeira seção estabelece o quadro teórico, diferenciando e relacionando os conceitos de "campo discursivo [feminista]" (Sonia Alvarez), "matriz discursiva" (Eder Sader) e "contrapúblico [subalterno]" (Nancy Fraser). A segunda seção aborda a institucionalização do "feminismo popular" em direção aos CDCMs enquanto a terceira seção analisa a gênese discursiva do "feminismo periférico". Por fim, as considerações finais comparam as matrizes discursivas dos dois momentos a fim de apreender mudanças estruturais em alguns dos contrapúblicos (feministas ou não) da Zona Leste de São Paulo.

\section{Quadro teórico: campo discursivo, matrizes discursivas e contrapúblicos}

Alvarez (2014a) apresentou recentemente um diagnóstico amplo, e, ao mesmo tempo, sintético dos feminismos latino-americanos. Em vez de falar em "o movimento feminista", a autora propõe uma "nova unidade de análise" ao interpretar os feminismos como constituindo um campo discursivo de ação (ALVAREZ, 2014a, p. 16). Esta sua abordagem começou a ser desenvolvida na década de 1990 para dar conta da complexificação do feminismo latinoamericano. O objetivo original de Alvarez (1998) com este conceito era duplo: de um lado, negar, na época, que haveria um abismo intransponivel entre as chamadas ONG's feministas e "o movimento feminista" ao demonstrar a persistência de referências discursivas comuns entre as práticas feministas mais formalizadas (como as ONG's dos anos 80-90) e as menos formalizadas (como os coletivos autônomos dos anos 70-80); de outro, reconhecer a existência de relações desiguais de poder no interior deste campo de movimento social. Assim, o conceito de campo discursivo afirmaria simultaneamente a multiplicidade dos espaços de atuação das feministas, a sua unidade discursiva e a desigualdade entre as atoras sociais e politicas. 
Do "feminismo popular" ao "feminismo periférico" | Jonas Medeiros

Quando explicita a definição madura deste conceito, Alvarez afirma que "alguns dos elementos que conformam um campo discursivo de ação" são:

1) atoras/es mais ou menos visiveis, hegemônicos, marginalizados; 2)
malhas/teias/redes articuladoras; 3) pontos nodais; 4) dimensões
verticais, horizontais, e talvez densidade; 5) discursos definidores; 6)
lutas interpretativas/conflitos constitutivos; e 7) paradoxos
transformadores (ALVAREZ, 2014a, p. 46).

Alvarez (2014a) apresenta então três momentos das trajetórias dos campos feministas brasileiro e latino-americano. O primeiro momento é caracterizado pelo "centramento" do campo discursivo de ação e a configuração do "feminismo no singular". A partir da década de 1970, um "componente [...] central da gramática política compartilhada que articulava o incipiente campo feminista" foi a dicotomia "luta geral-militância politica" versus "luta específica-militância autônoma" (ALVAREZ, 2014a, p. 22). O “exterior constitutivo" do campo neste momento foram principalmente os partidos e grupos politicos de esquerda, muitos deles revolucionários. Além da valorização da autonomia, as "feministas fundadoras" estavam no campo da oposição à ditadura militar, se organizavam em coletivos e realizavam regularmente manifestações de rua. A referida "luta específica" tornou-se um traço do feminismo hegemônico neste momento; contudo, para muitas mulheres, ela estaria "profundamente marcada pela classe social, a heteronormatividade, e uma branquidade 'inominada' ou implicita que constituía um pano de fundo silenciado" (ALVAREZ, 2014a, p. 23). ${ }^{6}$

Já o segundo momento é caracterizado pelo descentramento e a pluralização dos feminismos, além do mainstreaming (fluxos verticais) do gênero. Se, antes, a principal forma de organização eram os coletivos autônomos, um dos principais nós articuladores do campo feminista passaram a ser, na década de 90, ONG's, com "sedes permanentes, orçamentos expressivos, departamentos especializados, e pessoal remunerado". As ONG's "transnacionalizadas, profissionalizadas e especializadas" passaram a conformar "um núcleo hegemônico do campo feminista" (ALVAREZ, 2014a, p. 26). Este novo momento também viveu um

\footnotetext{
6 Mesmo com estas críticas, a autora sustenta que o campo feminista já era nos anos 1970 e 80 "plural e heterogêneo". Havia "alianças e coligações" entre "mulheres de classe média" e outras mulheres, pobres, negras ou lésbicas, assim como surgiram, já no final da década de 70 , organizações de mulheres negras, autônomas tanto do movimento feminista branco quanto do movimento negro misto (ALVAREZ, 2014a, p. 24).
} 
reposicionamento de várias atoras "para além da sociedade civil"; a autora chama isto de uma "articulação vertical", ou seja, em direção à sociedade política e ao Estado, além de partidos eleitorais, governos, universidades e instituições internacionais como ONU e Banco Mundial. Um outro nó articulador, também situado "para além da sociedade civil", específico ao campo feminista brasileiro, foi o Partido dos Trabalhadores (PT), junto com sindicatos, movimento dos sem-terra, os movimentos populares ligados à Igreja Católica, movimentos estudantis, além de grupos feministas dentro das administrações municipais e estaduais do partido (ALVAREZ, 2014a, p. 2728).

Por fim, o terceiro (e atual) momento é marcado pela multiplicação de campos feministas e o sidestreaming (fluxos horizontais) no interior destes feminismos plurais. Alguns dos discursos articuladores passam a ser a "desigualdade" (em especial a desigualdade racial, que ganha centralidade para as militantes mais jovens, desembocando em novos campos, como o do feminismo negro) e o da "autonomia". Mesmo com mulheres negras, jovens e populares alcançado grande visibilidade neste novo momento, ainda há continuidades de certas características do segundo momento: as ONGs transnacionais continuam fortes, além dos centros de estudos feministas e/ou de gênero nas universidades estarem ainda mais consolidados. Se aquelas ONGs especializadas e profissionalizadas eram um nó articulador no segundo momento, agora o próprio Estado precisa ser considerado um dos "principais articuladores do campo [feminista] brasileiro hoje em dia" (ALVAREZ, 2014a, p. 44), com as Conferências Nacionais de Políticas para as Mulheres (em 2004, 2007 e 2011) e o que algumas autoras estão chamando de "feminismo estatal participativo" ou então de "ativismo institucional" (ABERS; TATAGIBA, 2015). A autora sinaliza que a absorção tecnocrática do gênero por governos e instituições internacionais, além da "ONGização e transnacionalização do advocacy feminista" levaram a mais desigualdades, conflitos e, por fim, a "novos paradoxos que propulsaram mudanças no campo feminista da região [da América Latina]" (ALVAREZ, 2014a, p. 32). ${ }^{7}$ Esta noção de "paradoxos

\footnotetext{
7 Conforme o diagnóstico da autora é anterior ao fim da chamada "onda rosa" na América Latina, os retrocessos políticos, institucionais e legais no âmbito do gênero e da sexualidade não tinham como ser incorporados à sua análise naquele momento. Para os propósitos conceituais e empíricos deste artigo isto não é prejudicial, considerando que minha própria pesquisa de campo se encerrou em 2016, quando já havia sinais de retrocessos (MEDEIROS, 2017, p. 222-223) porém antes da eleição e posse de Jair
} 
Do "feminismo popular" ao "feminismo periférico" | Jonas Medeiros

transformadores" não é aprofundada até as últimas consequências, mas pode render interessantes hipóteses explicativas para a dinamicidade do campo feminista, como alude a própria autora em um outro artigo: "paradoxos são o que movem os movimentos" (ALVAREZ, 2014b, p. 73). ${ }^{8}$

Como afirmado previamente, um outro discurso articulador é o da autonomia. Depois do segundo momento ser marcado por processos de institucionalização (os "fluxos verticais"), o feminismo parece viver uma "volta" aos anos 70 (lembrando que o primeiro momento era organizado em torno de coletivos autônomos). Há tanto uma crítica na aposta do segundo momento na formulação e implementação de políticas públicas quanto um "desincentivo material aos formatos mais "institucionalizados" devido ao deslocamento da cooperação internacional "para outras partes do 'Sul Global' em consequência do tão celebrado (e talvez efêmero) crescimento latino-americano da década dos 2000" (ALVAREZ, 2014a, p. 36). A política institucional, a gestão pública e financiamentos como os da Fundação Ford são reavaliados como insuficientes para a luta feminista. Um exemplo de como a autonomia passa a ser um discurso articulador do campo é a sua reivindicação por vertentes extremamente heterogêneas do "feminismo jovem", como as anarcoautonomistas, as militantes de partidos trotskistas (como o PSTU) mas também a Marcha Mundial das Mulheres (coordenada pela ONG Sempreviva Organização Feminista e vinculada a uma tendência do PT), independentemente de suas pluralidades, contradições e conflitos. A multiplicação de campos feministas e seus fluxos horizontais seriam, portanto, as principais marcas do profundo processo de complexificação dos feminismos contemporâneos na América Latina.

A "principal dívida teórica na formulação" da noção de campo discursivo de ação "é com a literatura brasileira sobre campos 'ético-políticos", como as obras de Sérgio Baierle, Ana Maria Doimo e Eder Sader (ALVAREZ, 2014a, p. 16). Gabriel Feltran (2005) acrescenta, por sua vez, que, além destes

\footnotetext{
Bolsonaro como presidente da república. Para uma tentativa de estender o quadro teórico de Alvarez neste contexto de retrocessos e de passagem das lutas feministas ofensivas para as defensivas, cf. Medeiros e Fanti (2019).

8 “[Nós percebemos que os] paradoxos que identificamos eram vividos como tensões, trazendo [a] história pessoal e [a] coletiva para o presente, e esses desconfortos agudos [pressionaram] as mulheres a agirem. [Paradoxos davam movimento] aos próprios movimentos, pressionando-os a concretizar o futuro enquanto [se] moviam no tempo" (RUBIN; SOKOLOFF-RUBIN apud ALVAREZ, 2014b, p. 73, n. 16; tradução alterada e complementada por mim com os acréscimos destacados por colchetes).
} 
autores, Alvarez e Dagnino também desenvolveram a categoria de campo político, aproximando-a dos conceitos de matrizes discursivas de Sader e de contrapúblicos de Nancy Fraser. ${ }^{9}$ Contudo, quero aqui defender que a própria categoria de campo discursivo de Alvarez pode ser melhor entendida e operacionalizada ao não ser reduzida a um sinônimo de matriz discursiva e de contrapúblico (embora os conceitos possam e devam ser relacionados).

Sader elaborou a categoria de matrizes discursivas em seu estudo sobre os movimentos sociais e a entrada, no decorrer da década de 1970, das classes populares no cenário público brasileiro. O autor estava preocupado com a emergência de novos significados, ou seja, na forma pela qual os sujeitos atribuem novos sentidos à sua vida cotidiana, reelaborando-a simbolicamente; contudo

\begin{abstract}
Os sujeitos não são livres para produzir seus discursos e nem podem inventar na hora seus sistemas de comunicação. Eles recorrem a matrizes discursivas constituídas e, em primeiro lugar, à matriz da própria cultura instituída, reproduzida através de uma pluralidade de agências sociais. Mas encontramos na sociedade agências que, embora participando da cultura instituída (condição para que haja comunicação social), expressam práticas de resistência e projetos de ruptura. Constituem novas formas de agenciamento social, que abrem espaço para a elaboração de experiências até então silenciadas ou interpretadas de outro modo. As matrizes discursivas devem ser, pois, entendidas como modos de abordagem da realidade, que implicam diversas atribuições de significado. Implicam também, em decorrência, o uso de determinadas categorias de nomeação e interpretação (das situações, dos temas, dos atores) como na referência a determinados valores e objetivos. Mas não são simples ideias: sua produção e reprodução dependem de lugares e práticas materiais de onde são emitidas as falas (SADER, 1988, p. 142-143).
\end{abstract}

Conforme os discursos são indissociáveis destes "lugares e práticas materiais", Sader estava interessado em descobrir "centros de elaboração discursiva" que possibilitariam às classes populares reelaborarem suas próprias experiências e vivências. Tal reelaboração nada mais seria do que uma mediação simbólica entre as estruturas sociais objetivas e as ações coletivas: um processo de atribuição de novos significados às condições de

\footnotetext{
9 "Outra contribuição importante para pensar a categoria de campo político foi dada em seguida por Doimo (1995) e por Sonia Alvarez e Evelina Dagnino (1995), que utilizaram-se da expressão 'campo ético-político', as últimas relacionando as matrizes discursivas de Sader à ideia de counterpublics (espaços públicos alternativos) de Nancy Fraser, bem como à noção de 'princípio ético-político', utilizada por Sérgio Baierle (1995), com inspiração gramsciana. As autoras afirmam que 'discursos e práticas dos movimentos sociais demarcaram [até aquele momento] um campo comum de referências e diferença para a ação coletiva e contestação coletiva', delimitando um novo 'campo ético-político' na sociedade. Era nesse campo, legitimado pela explicitação de injustiças inegáveis, que os movimentos sociais apoiavam suas lutas" (FELTRAN, 2005, p. 213).
} 
Do "feminismo popular" ao "feminismo periférico" | Jonas Medeiros

existência experienciadas pelos sujeitos. As matrizes discursivas podem ser entendidas, deste modo, tanto no seu caráter institucional, como no de constituírem esferas públicas (muitas vezes informais) e que podem ser apreendidas como redes de sociabilidade que, pela interação social intersubjetiva, podem contribuir com a ressignificação crítica e reflexiva da vida cotidiana e permitir a emergência de ações coletivas.

Em seu estudo empírico acerca de quatro movimentos populares - o Movimento de Custo de Vida, a Oposição Metalúrgica de São Paulo, o Movimento de Saúde da Zona Leste e o Sindicato dos Metalúrgicos de São Bernardo - Sader identificou três matrizes discursivas: a Teologia da Libertação, o marxismo e o novo sindicalismo. Em comum as três matrizes discursivas emergem de instituições - o que Sader antes havia se referido à "cultura instituída" - em crise: (i) a Igreja Católica; (ii) a esquerda revolucionária; e (iii) a estrutura sindical. Cada crise específica é interpretada como a gênese de novas práticas - o que Vera Telles se referia como "práticas instituintes". Estas novas práticas paulatinamente se institucionalizam abordagem coerente com a fenomenologia de Berger e Luckmann (1983), segundo a qual "a realidade objetiva [é pensada] como o resultado das ações sociais que se objetivaram" (SADER, 1988, p. 47). Cada uma das três vias de institucionalização resulta em lugares sociais de onde se emitem falas, mensagens e discursos: (i) as Comunidades Eclesiais de Base; (ii) organizações e jornais clandestinos; (iii) sindicatos que integram a institucionalidade estatal mas que buscam se reconectar às suas bases. As falas emitidas destes lugares se orientam para um público de ouvintes, para os quais estes discursos podem ou não ter ressonância e aderência. Por último, interessa a Sader identificar os temas e enunciados que emergem destas práticas institucionalizadas em lugares sociais de fala, pois seus conteúdos viabilizaram reelaborações simbólicas de experiências populares, o que foi fundamental para a emergência dos movimentos sociais que ele analisa no último capítulo de seu livro.

O que mais me interessa reter é a interpretação de que a categoria de matrizes discursivas de Sader pode ser melhor compreendida a partir do conceito de esfera pública (HABERMAS, 2014), o que se torna possível ao 
acompanhar como as noções de "público" e "publicidade" aparecem em cada uma das três matrizes discursivas (MEDEIROS, 2017, p. 98-100). ${ }^{10}$

A crítica de Fraser a Habermas é útil para avançar uma atualização do quadro teórico de Sader - as esferas públicas enquanto matrizes discursivas - tendo em vista as especificidades do feminismo. A princípio, Fraser reconhece a importância da categoria habermasiana da esfera pública para uma teoria crítica dos "limites da democracia em sociedades do capitalismo tardio" (FRASER, 1992, p. 109). Embora defenda que a ideia de Habermas da esfera pública seja indispensável para a teoria social critica pois designa uma arena discursiva que é irredutivel ao Estado ou ao mercado, Fraser aponta que a forma pela qual ele a elaborou não foi satisfatória. A partir de uma historiografia revisionista acerca da participação das mulheres na esfera pública (principalmente os trabalhos de Joan Landes e Mary Ryan, mas também de Geoff Eley), Fraser apresenta questionamentos à concepção burguesa e masculinista da esfera pública tal como descrita por Habermas. Tendo em vista estas críticas e aquela historiografia das esferas públicas, Fraser propõe o conceito de contrapúblicos subalternos ${ }^{11}$ :

Esta historiografia registra que os membros de grupos sociais subordinados - mulheres, trabalhadores, pessoas de cor e gays e lésbicas - tem considerado repetidamente vantajoso constituir públicos alternativos. Eu proponho chamá-los de contrapúblicos subalternos para assinalar que eles são arenas discursivas paralelas nas quais membros de grupos sociais subordinados inventam e circulam contradiscursos para formular interpretações oposicionais de suas identidades, interesses e necessidades. Talvez o exemplo mais notável seja o contrapúblico subalterno feminista nos Estados Unidos no final do século XX, com seu arranjo variado de jornais, livrarias, editoras, redes de distribuição de filmes e vídeos, séries de palestras, centros de pesquisa, programas acadêmicos, conferências, convenções, festivais e pontos de encontro locais. Nesta esfera pública, mulheres feministas inventaram novos termos para descrever a realidade social, incluindo "sexismo", "a dupla jornada", "assédio sexual" e "estupro marital". Armadas com esta linguagem, nós reformulamos nossas necessidades e identidades, desta forma reduzindo, embora não eliminando, o alcance de nossa desvantagem nas esferas públicas oficiais (FRASER, 1992, p. 123; meu grifo).

\footnotetext{
10 O uso da tradução francesa d'A mudança estrutural da esfera pública (intitulada L'espace public) leva Sader a se referir frequentemente a "espaço público", em vez de "esfera". Autores que continuaram sua agenda de pesquisa sobre movimentos sociais (ao menos até o início dos anos 2000), como Telles e Feltran utilizam sempre o conceito de "espaço público", mas sua interlocutora privilegiada é Arendt e não Habermas. Acredito ser relevante frisar a inspiração habermasiana da pesquisa de Sader a fim de atualizá-la de modo profícuo.

11 Fraser cunhou a categoria combinando os termos "subalterno" e "contrapúblico", respectivamente das teóricas literárias Gayatri Spivak e Rita Felski.
} 
Do "feminismo popular" ao "feminismo periférico" | Jonas Medeiros

Tais "públicos alternativos" ou "arenas discursivas paralelas" por meio das quais "contradiscursos" e "interpretações oposicionais" são produzidas e depois circulam são conceitualizações muito próximas do que Sader chamou de matrizes discursivas pois tanto estas quanto os contrapúblicos subalternos têm como função inventar uma nova linguagem e "novos termos para descrever a realidade social" a fim de reformular - Sader diria: reelaborar simbolicamente - "necessidades e identidades".

Defendo que a melhor forma de articular os conceitos acima apresentados é a seguinte: o campo discursivo surge a partir de um imbricamento crescente entre contrapúblicos subalternos e públicos dominantes $^{12}$ (ALVAREZ, 1998, p. 316). Já as matrizes discursivas funcionam como categorias analiticas, que apreendem processos socioculturais nos quais determinados contrapúblicos desempenham o papel de fornecer discursos oposicionais que facilitam a emergência de ações coletivas. Cada categoria tem uma produtividade específica: enquanto a noção de campo discursivo serve para apontar o compartilhamento de referências comuns para práticas múltiplas e desiguais, a noção de matriz discursiva serve para apontar a diversidade de instituições que contribuem diferencialmente para movimentos sociais na produção e circulação de "códigos oposicionais" (cf. HALL, 1999). ${ }^{13}$

Com a referência conceitual de campo discursivo feminista, é possível se perguntar se o conjunto do que chamei em minha tese (MEDEIROS, 2017, p. 46-50), inspirado pela teoria do processo político de Sidney Tarrow e Doug McAdam, de dois ciclos politicos - o "feminismo popular" e o "feminismo periférico" - não podem ser melhor interpretados como momentos históricos de um mesmo (sub)campo feminista na Zona Leste de São Paulo. Seguindo Alvarez, isto evitaria focar apenas nos "fluxos e refluxos" dos movimentos, alterando a visada para o caráter permanente, porém dinâmico, da mobilização feminista. Esta noção de campo (mesmo que territorializada regionalmente como um subcampo) pode ser útil para abranger alguns fenômenos que Alvarez (2014a) também analisa, como os "nós articuladores" e os "fluxos verticais" (da sociedade civil em direção à sociedade política, dos

\footnotetext{
12 Os chamados fluxos verticais, em direção a ONG's, ao Estado e a organismos internacionais.

13 Hall nunca explicitou as condições sociais de possibilidade de códigos oposicionais. Minha hipótese com relação a esta questão iguala as "comunidades interpretativas" às quais o autor se referiu em uma outra ocasião (HALL, 2003, p. 378-381) aos contrapúblicos.
} 
contrapúblicos subalternos em direção ao seu imbricamento com públicos dominantes). Desta forma, seria produtivo não considerar isoladamente, de um lado, as associações e movimentos do primeiro ciclo/momento e, de outro, os coletivos do segundo ciclo/momento. Seria preciso também dar conta do principal fluxo vertical identificado, o desenvolvimento do "feminismo popular" em direção à institucionalização, sob a forma dos CDCMs. E também da emergência simultânea da Rede Leste de Enfrentamento à Violência e dos coletivos feministas periféricos, o que me levou a pensar a sua relação a partir da noção de paradoxos transformadores. Assim, passa a ser possível construir uma narrativa unificada da dinâmica interna do subcampo feminista na Zona Leste de São Paulo.

\section{O “feminismo popular”: dos contrapúblicos aos públicos (fluxos verticais)}

A rede organizacional de associações feministas populares na Zona Leste de São Paulo compartilha várias características com os movimentos sociais que Sader analisou. Identifiquei como matrizes discursivas do "feminismo popular", três instituições com seus respectivos espaços de sociabilidade: (1) a Igreja Católica, na sua vertente progressista da Teologia da Libertação e os espaços das Comunidades Eclesiais de Base (CEBs); (2) ONGs integrantes do movimento feminista, fundadas principalmente no decorrer das décadas de 1980 e 90, cujas sedes não se localizam na Zona Leste, mas que realizavam trabalho de base em bairros periféricos; e (3) o "mundo do carnaval", com suas escolas de samba e blocos afro, tanto no Centro quanto espalhadas pela Zona Leste, enquanto um espaço de resistência da cultura negra. Além disso, é importante frisar que todas as entrevistadas de cada um destes grupos são ${ }^{14}$ ou foram ${ }^{15}$ filiadas ao PT.

Quatro das associações feministas populares surgiram no seio das CEBs, com as militantes entrevistadas enfatizando a relevância da Teologia da Libertação para a formação de sua visão de mundo e sua atuação política. ${ }^{16}$

\footnotetext{
14 Amzol, Lilith, São Miguel, Oriashé e Dandara.

15 São Mateus e Fala Negão (uma associação mista; a mãe da entrevistada, sua fundadora, já é falecida). 16 A Amzol reuniu comunidades e clubes de mães de paróquias do Itaim Paulista e região; a Casa da Mulher Lilith antes era um grupo de mulheres que se reunia na Paróquia Nossa Senhora do Carmo da Vila Alpina (em Vila Prudente); o Movimento de Mulheres de São Miguel é criado no interior do Movimento de Saúde da Zona Leste (MSZL) que, por sua vez, surge na Paróquia de Santa Luzia, no Jardim Nordeste (em Artur Alvim); e, por fim, o Coletivo de Mulheres de São Mateus utilizava para realizar algumas de suas reuniões a Paróquia São Mateus Apóstolo (em São Mateus).
} 
Do "feminismo popular" ao "feminismo periférico" | Jonas Medeiros

Há nos depoimentos das entrevistadas dois sentidos atribuídos às CEBs e à Igreja Católica que podem ser compreendidos como características de um contrapúblico subalterno: de um lado, espaço de sociabilidade e lazer, de outro, espaço de formação política. A ex-integrante do Coletivo de São Mateus explica que, sem opções de lazer na periferia (no decorrer da década de 1980), a igreja "era o ponto de encontro"17; mas conforme as CEBs eram um local que "fazia a oração ir pra ação", além de espaço de encontro, também eram “espaço de reflexão das pessoas". A presidente da Amzol explica, por sua vez, que com a "mulherada dentro das igrejas", criaram-se "espaços para as pessoas falarem", ou seja: compartilharem as histórias de seu lugar, como chegaram neste bairro dormitório (ela se referia ao Itaim Paulista), apontar o que ali faltava e, deste modo, lutar para alcançar conquistas no sentido de suprir estas carências. Além de encontrar um "calor humano na igreja", todas as entrevistadas são unânimes em apontar o caráter formativo da participação nas comunidades católicas; elas chegam a atribuir às CEBs o que ocorreu de mais fundamental nas suas trajetórias de militância: enquanto a fundadora da Casa Lilith afirma "eu me formei nas discussões de formação das CEBs", a militante do Movimento de São Miguel (e atual diretora do MSZL) defende que "A força que eu tenho pra lutar no movimento, eu adquiri com a Igreja de Dom Angélico18". Segundo a presidente da Amzol, “Dom Angélico foi um bispo revolucionário". No caso de São Mateus e de Vila Prudente (distrito onde se localiza o bairro da Vila Alpina, onde eram desenvolvidas as atividades da Casa Lilith), o responsável por levar a cabo estas mesmas diretrizes, era Dom Luciano Mendes de Almeida, responsável pela Região Episcopal Belém, a qual permanece até hoje ligada diretamente à Arquidiocese de São Paulo. Como explica a fundadora da Casa Lilith, as CEBs foram um "espaço que nos deu muita força e conhecimento para enfrentar a ditadura militar" e "as pessoas cresceram muito nesse processo". Pude identificar no discurso destas associações um

\footnotetext{
17 Além de ter escrito a tese inteira na primeira pessoa do singular (repetir o "nós" pregado na academia me pareceu um convite para a reprodução e naturalização do homem branco como o sujeito universal do conhecimento, enquanto que o "eu" me remarca enquanto tal, evitando falsificações ideológicas) eu também sempre destaquei em negrito as falas de minhas interlocutoras.

18 Dom Angélico Sândalo Bernardino foi bispo auxiliar de São Miguel, entre 1975 e 89, tendo organizado pastorais, paróquias e comunidades no sentido defendido por Dom Paulo Evaristo Arns, arcebispo de São Paulo, na linha progressista do Concílio Vaticano II (IFFLY, 2010).
} 
tensionamento da Teologia da Libertação em direção a uma Teologia Feminista da Libertação (TOMITA, 2004).

No caso da matriz discursiva diretamente feminista, os "centros de elaboração discursiva" são o que chamei na tese de "ONGs feministas centrais" - com sedes localizadas na região central ou na Zona Oeste da cidade de São Paulo. ${ }^{19}$ Da mesma forma que a matriz discursiva da esquerda exrevolucionária, analisada por Sader, forneceu explicações teóricas marxistas para as pastorais e os movimentos populares, aqui, é esta articulação de ONGs constituindo um contrapúblico subalterno feminista que forneceu explicações teóricas feministas e de gênero para as associações de mulheres da Zona Leste. A relação entre teoria e prática era vivida pelas militantes do "feminismo popular" por meio da atribuição de um caráter exterior à teoria feminista. ${ }^{20}$

Na maioria dos casos há uma colaboração histórica com a Sempreviva Organização Feminista (SOF) e uma identificação com a Marcha Mundial das Mulheres (MMM); contribuiu para isto a manutenção até meados da década de 1990 de uma sede da SOF em uma casa em São Miguel (onde também funcionou por algum tempo ao lado a sede da Amzol). Além disso, as atividades da Amzol, em sua origem, no começo dos anos 80 são, em grande parte, uma pesquisa-ação participante da RME-Rede Mulher de Educação (VIEZZER, 1989); já na década de 1990, a Amzol participou do $1^{\circ}$ curso de Promotoras Legais Populares (PLPs), promovido principalmente pela UMSPUnião de Mulheres do Município de São Paulo (RICOLDI, 2005), o que foi fundamental para que em 1996 fosse aberto o Centro Jurídico Maria Miguel. Para a Casa da Mulher Lilith, a colaboração mais longeva foi com o CFSSColetivo Feminista Sexualidade e Saúde (COLETIVO FEMINISTA SEXUALIDADE E SAÚDE, 2000), com o qual as militantes da Vila Alpina publicaram a revista semestral Enfoque Feminista e tiveram auxílio com o

\footnotetext{
19 ONGs como: Sempreviva Organização Feminista, Rede Mulher de Educação, União de Mulheres do Município de São Paulo, Coletivo Feminista Sexualidade e Saúde, Geledés, Católicas pelo Direito de Decidir e Fala Preta!. Algumas pesquisas empíricas realizadas acerca destas ONGs "centrais" podem auxiliar na compreensão do papel de assessoria técnica que elas prestaram para as associações feministas populares: no caso da SOF e da RME (GOMIDE, 2002) e no caso da UMSP (OLIVEIRA, J., 2013). Para uma compreensão abrangente da história do movimento feminista na cidade de São Paulo, cf. Fanti (2016).

20 Como me explicou a então presidente da Associação de Mulheres da Zona Leste: “A Amzol não tem parte teórica. Nós somos mais da prática, mas a parte teórica veio da Católicas pelo Direito de Decidir, muito do [sic] SOF e da Rede Mulher de Educação"; outra entrevistada, pelo Movimento de Mulheres de São Miguel, formula a relação com a assessoria técnica feminista da seguinte maneira: "Quem nos ensinou a gritar foi o [sic] SOF".
} 
Do "feminismo popular" ao "feminismo periférico" | Jonas Medeiros

boletim bimestral Lilith Informa. Por fim, as entidades deste ciclo que inovaram ao tematizar explicitamente a questão da mulher negra mantiveram alianças e parcerias com as ONGs feministas centrais que foram pioneiras no feminismo negro: as ONGs Geledés e Fala Preta (CARLOS, 2009; SANTOS, S., 2008) passavam editais de financiamento para o Dandara (e a Fala Negão / Fala Mulher!), enquanto que o Oriashé promoveu em colaboração com o Geledés dois cursos de formação de PLPs na Cidade Tiradentes.

Justamente nestes últimos casos, que privilegiaram em suas práticas e seus discursos a questão racial, verifica-se que há, no interior do "feminismo popular" uma espécie de substituição da matriz discursiva católica; se na maioria dos casos há um encontro entre a Teologia da Libertação e as "ONGs feministas centrais", nos casos minoritários - do Espaço Lilás e do Dandara , estas agências de mediação feministas estão presentes, mas no lugar das CEBs está o que uma delas chamou de "o mundo do samba" e do carnaval. Suas lideranças entrevistadas não são católicas e sim praticantes do candomblé2 ${ }^{1}$. Como explica a entrevistada pelo Grupo Cultural Dandara, foi o samba quem the deu sua identidade racial, principalmente por conta da escola de samba que ela frequentava na Vila Formosa, distrito da Zona Leste. Já no caso do Oriashé (cujo nome oficial é "Oriashé - Sociedade de Cultura e Arte Negra"), que depois criou o Espaço Lilás, foi, originalmente, um dos primeiros blocos afro composto apenas por mulheres negras, fundado no final da década de 1980 no Bixiga, região central da cidade (CASTRO, 2008; MENDONÇA, 1993); com a saída de uma das suas fundadoras do Bixiga para a Cidade Tiradentes (a entrevistada, que inclusive foi militante do MNU-Movimento Negro Unificado), as mulheres que permaneceram no Centro criam, alguns anos depois, o Bloco Afro Ilú Obá de Min (SOUZA, 2014). Se a Associação Fala Negão / Fala Mulher! (de composição mista) for considerada, sua origem também está no mundo do carnaval: uma das principais entidades que participou de sua fundação é a Leandro de Itaquera, uma escola de samba com grande participação de negros e um discurso crítico com relação à questão racial (OLIVEIRA, K., 2002).

As escolas de samba e os blocos afro, em sua conexão com diferentes organizações do movimento negro, se constituem como um contrapúblico

\footnotetext{
${ }^{21}$ Nação jêje mahin no caso da fundadora do Oriashé e nação ketu no da entrevistada pelo Dandara.
} 
negro 22 : espaços de sociabilidade nos quais a cultura é vivida como base para a construção da identidade racial e como resistência negra; é a partir destes sentidos e significados que um número minoritário das militantes do "feminismo popular" puderam esboçar práticas e discursos que não invisibilizassem as questões específicas das mulheres negras. ${ }^{23}$

A gênese do "feminismo popular" está na articulação combinada destes três contrapúblicos acima apresentados. Aos poucos, não apenas estas associações de mulheres constituem elas próprias um novo contrapúblico feminista popular - como também passam a desenvolver fluxos verticais, em direção a públicos dominantes (em especial a Prefeitura de São Paulo, por meio da constituição de novas ONG's), o que permite caracterizar este processo de complexificação e institucionalização das práticas feministas na Zona Leste como a emergência de um subcampo discursivo feminista.

O principal repertório de ação coletiva das associações feministas populares - o atendimento jurídico e psicológico a mulheres em situação de violência - começou a ser institucionalizado já na década de 90 . O primeiro passo foi o convênio da Amzol com a Procuradoria Geral do Estado de São Paulo (PGE-SP), com a criação em 1996 do Centro Jurídico Maria Miguel, em decorrência do curso de formação de PLPs, e que forneceu atendimento jurídico gratuito a cerca de 18 mil mulheres em menos de 10 anos. Já a partir do governo Marta Suplicy (2001-04; então no PT), há um salto no fluxo vertical por meio da política pública de assistência social. ${ }^{24}$

22 Hanchard aponta uma suposta singularidade latino-americana com relação à questão racial nos
Estados Unidos ou no Caribe: "o colapso retórico da diferença racial sob a bandeira da identidade
nacional" (HANCHARD, 1994, p. 181). A ausência das formas de segregação racial comuns nos Estados
Unidos ou na África do Sul tornam, segundo o autor, a pergunta "o que é a cultura afro-brasileira?"
mais complexa no caso do nosso país. Historicamente, "A cultura nacional brasileira sempre traduziu e
transformou práticas culturais afro-brasileiras como práticas culturais nacionais, tornando-as, deste
modo, mercadorias na cultura popular a serem consumidas por todos" (HANCHARD, 1994, p. 182). Esta
operação cultural passou a ser questionada com a emergência do movimento negro brasileiro
contemporâneo, em meados da década de 1970, e os espaços de sociabilidade que constituíram sua
gênese, como os bailes Black Soul e os blocos afro (como Olodum e Illê Aiyê), "que produzem letras e
músicas que utilizam a identidade afro-brasileira e a discriminação racial como seu principal tema"
(HANCHARD, 1994, p. 181). Reivindicando práticas culturais que antes eram "desracializadas" como
"cultura nacional", estas iniciativas foram essenciais para criar uma esfera pública alternativa, ou seja,
um contrapúblico negro, que possibilitasse o uso da "identidade racial como um principio para organizar
a ação coletiva" (HANCHARD, 1994, p. 182).
23 Correia aponta, em seu estudo empírico que abrange a Amzol, como "a temática racial se insere de
forma tímida" e como "o debate racial ainda não era priorizado" (CORREIA, 2015, p. 48). Neste sentido,
é possivel atribuir ao Oriashé e ao Dandara a antecipação de certas características do próximo momento
histórico, como será visto adiante.
24 Em 2014, a SMADS contabilizava 1190 serviços. Apenas $6,3 \%$ são serviços diretos, da Prefeitura
Municipal de São Paulo (todos os 49 CRAS-Centros de Referência de Assistência Social; os 24 CREAS-
Centros de Referência Especializado de Assistência Social; e os 2 Centros POP-Centros de Referência
Especializado para População em Situação de Rua). Os outros 93,7\% dos serviços da SMADS são 
Os sete CDCMs da Zona Leste 25 têm dois momentos históricos de suas fundações: a "primeira geração" (a Casa Cidinha, em 2002, e a Casa Viviane, em 2004, ambas na gestão Marta) 26 e a "segunda geração" (todos são de 2012, no final da gestão do prefeito Gilberto Kassab, do PSD: Casa Anastácia; Casa Zizi; MulherAção; e Maria da Penha; com exceção do Naná Serafim, inaugurado em 2013, já no primeiro ano da gestão de Fernando Haddad, do PT). Hoje, estes CDCMs integram a Rede Leste de Enfrentamento à Violência, junto com outras organizações que não são convênios. ${ }^{27}$

Mais da metade (4) destes CDCMs têm por trás dos convênios entidades com origem na Igreja Católica: Associação Padre Moreira (no caso da Casa Cidinha); AVIB-Associação de Voluntários Integrados no Brasil (nos casos da Casa Viviane e da Casa Anastácia); e CIAP ${ }^{28}$ São Patrício (no caso da Casa Zizi). Estas três entidades tiveram alguma relação inicial com as CEBs de sua respectiva região, ou na década de 1980 ou de 1990: a Padre Moreira nos distritos São Rafael e São Mateus; a AVIB nos distritos de Guaianases e Lajeado; e o CIAP São Patrício no distrito de Sapopemba.

Já no caso dos outros CDCMs não se verificou a centralidade religiosa, católica ou não: a Casa de Isabel, uma ONG de combate à violência contra a mulher fundada em 1996 (no caso do CDCM “Projeto Naná Serafim”); a Rede Criança de Combate à Violência, uma ONG iniciada em 1998 e com vínculos politicos com o PCdoB (no caso do CDCM Maria da Penha); e o Instituto Social

convênios com 1575 organizações diferentes (dentre os quais: os CCAs-Centros para Crianças e Adolescentes; os CJs-Centros para Juventude; os SASFs-Serviços de Assistência Social à Família; os NCIs-Núcleos de Convivência do Idoso; além de outras modalidades) - (MEDEIROS, 2017, p. 55). É neste contexto de parceria entre a Assistência Social municipal e entidades da sociedade civil que se deve começar a entender os CDCMs, embora isto não esgote nem determine por completo a sua atuação (SANTOS, C., 2015).

25 No ano de 2015, a cidade de São Paulo tinha 13 destes Centros: a maioria se localizava na Zona Leste mas também estavam presentes em outras regiões (3 na Zona Sul, 2 na Zona Norte e 1 na Região Central).

26 Entre 2003 e o início de 2005 funcionou um terceiro serviço, o Espaço Lilás na Cidade Tiradentes, mantido pelo Oriashé. Ao contrário das duas outras iniciativas, também oriundas da sociedade civil, o Oriashé - a única a trabalhar especificamente com a temática das mulheres negras - não contou com apoio da prefeitura petista para se institucionalizar, sob o formato de um convênio que financiasse suas atividades e um contrato que assegurasse a sua permanência na sede então cedida.

27 A Rede Leste também é composta por equipamentos públicos diretos ou então outros órgãos do poder público que não entram no escopo de minha investigação acerca do associativismo de mulheres por não terem relação com a sociedade civil (como é a situação das casas conveniadas). Além dos $7 \mathrm{CDCMs,} \mathrm{do}$ Agentes Bem Querer Mulher e das PLPs do Hospital de São Mateus, participavam da Rede Leste em 2015: o Centro de Cidadania da Mulher (CCM) Itaquera (então ligado à SMPM-Secretaria Municipal de Políticas para Mulheres); a Casa Abrigo Helenira Rezende de Souza Nazareth, conhecida como "Casa Helenira" (também ligada à SMPM); o Centro de Atenção à Saúde Sexual e Reprodutiva "Maria Auxiliadora Lara Barcellos", de Cidade Tiradentes, conhecido por "Casa Ser" ou "Casa Ser Dorinha" (ligada à SMS-Secretaria Municipal da Saúde); e o Núcleo Especializado de Promoção e Defesa dos Direitos da Mulher da Defensoria Pública do Estado de São Paulo (NUDEM/DPESP).

28 Centro de Assistência Social e Formação Profissional. 
Santa Lúcia, originalmente uma Associação de Moradores no distrito Jardim Ângela, Zona Sul de São Paulo, criada em 2000 (no caso do CDCM MulherAção).

É fundamental salientar que os CDCMs são, inicialmente, fruto de iniciativas da sociedade civil: o Coletivo de Mulheres de São Mateus está na origem da Casa Cidinha (informação fruto de entrevistas com a coordenadora da Casa e uma ex-integrante do Coletivo) e o Movimento "Abra os Olhos Companheira!" em Guaianases resultou na Casa Viviane (CORREIA, 2015; SILVA, 2014). Esta institucionalização dos movimentos de mulheres sob a forma de um convênio com a SMADS pode ser interpretada como um hibridismo: o grupo de mulheres passa a ser um braço do poder público e, simultaneamente, parte integrante da mobilização da sociedade civil. Contudo, as entrevistas que realizei evidenciam que este seu caráter híbrido não é vivenciado da mesma maneira por cada uma das casas conveniadas, revelando não apenas origens históricas diferentes mas também princípios politicos e sociais diferenciados.

Nos últimos anos começaram a surgir pesquisas empíricas sobre alguns dos CDCMs - Casa Viviane (LADEIRA, 2013; PINTO, 2016); Casa Anastácia (MARTINS, 2015); Casa Viviane e Casa Anastácia (CORREIA, 2015); Casa Cidinha (SOUZA, 2015); e PLPs do Hospital São Mateus (LORENZO, 2012; SOUZA; MACEDO; FERNANDES, 2014).

Um artigo recente de Cecília MacDowell Santos (2015) é provavelmente a primeira análise que abarca a Rede Leste como um todo. Além do mérito de trazer uma visão mais ampla do que os estudos de caso acima referidos, um segundo aspecto positivo deste trabalho é a busca por uma análise complexa que seja capaz de detectar a heterogeneidade do que ela chama de cultura jurídico-política do Estado. A autora realiza, assim, o mapeamento de diferentes abordagens ou perspectivas acerca da violência contra a mulher, às quais ela nomeia de: "familista", "de gênero", "feminista" e "interseccional de gênero, raça e classe", o que, nos termos de uma corrente da teoria dos movimentos sociais, poderia ser chamado de frames, ou seja, enquadramentos interpretativos. Contudo, um aspecto limitador do trabalho se encontra na sua proposta metodológica de uma "etnografia do Estado" o que, no meu entender, acaba por obscurecer o processo histórico de surgimento dos 
CDCMs a partir da sociedade civil. Minha opção neste artigo e em minha tese foi não por uma etnografia do Estado que buscasse mapear a cultura politica das e dos agentes do Estado e sim uma etnografia política que fosse capaz de apreender práticas muitas vezes informais, tais como os contrapúblicos construídos pelas próprias mulheres. Assim, defendo que a diversidade de atoras, repertórios e discursos só se torna inteiramente compreensivel quando se atribui centralidade à história das lutas sociais. ${ }^{29}$

Também é interessante a percepção, mesmo que superficial (pois baseada apenas em entrevistas com coordenadoras e assistentes sociais e não em observações participantes do dia a dia das casas conveniadas, as quais eu não realizei), de que todos os CDCMs entrevistados não cumprem um papel meramente assistencialista nem tampouco centrado apenas no aspecto penal da Lei Maria da Penha (o "D" de defesa ${ }^{30}$ ), mas com uma forte ênfase no aspecto da sociabilidade entre as mulheres (o " $\mathrm{C}$ " de convivência), assim como efetivando relevante papel no campo da educação jurídica popular,

29 A proposta da etnografia do Estado acaba por enfatizar demasiadamente uma perspectiva verticalizada, de "cima para baixo", apagando a pré-história da Rede Leste. Escreve a autora: "Até o início da década de 2000, não havia nenhum serviço (governamental ou não) especializado no atendimento a mulheres em situação de violência na Zona Leste de São Paulo" (SANTOS, C., 2015, p. 592). Minhas entrevistas trazem evidências contrárias a esta afirmação: como dito na seção anterior deste artigo, já na década de 1990, a Amzol (por meio do Centro Jurídico Maria Miguel, em parceria com a PGE-SP) e a Casa da Mulher Lilith mantinham serviços pioneiros que anteciparam o trabalho que seria depois realizado de modo mais formal e institucionalizado pelos CDCM's e pela Rede Leste. A coordenadora da Casa Cidinha (e ex-integrante do Coletivo de Mulheres de São Mateus) revelou em entrevista, por exemplo, que a prática da Casa da Mulher Lilith nos anos 90 inspirou a fundação do serviço conveniado em 2002. A agência das mulheres militantes do "feminismo popular" também acaba sendo diminuída no momento em que sua abordagem teórico-metodológica, mais centrada no Estado, privilegia atores institucionalizados: tanto no caso da Casa Cidinha quanto no da Casa Viviane, a narrativa da autora atribui centralidade às ONG's que mantém os serviços conveniados (Associação Padre Moreira e AVIB), em detrimento das organizações "feministas populares" (o Coletivo de Mulheres de São Mateus e o Movimento Abra os Olhos Companheira) - as entrevistas que realizei e os documentos e pesquisas que consultei demonstram que as duas ONG's católicas não "criaram" as casas (SANTOS, C., 2015 , p. 593 e 594) pois ambas tiveram muito menos agência na reivindicação e institucionalização dos serviços, sendo muito mais instrumentos formais requisitados pelo poder público para que as militantes feministas, com suas organizações informais (um "coletivo" e um "movimento"), alcançassem seus objetivos. Uma abordagem societal é, portanto, capaz de apreender de forma mais densa tais processos históricos complexos como a conexão entre o "feminismo popular" e a Rede Leste do que uma perspectiva centrada no Estado; os CDCM's são melhor compreendidos não como um serviço público descolado da história profunda do campo feminista, mas como um tipo de organização feminista construído analiticamente em comparação com as associações "feministas populares" e os coletivos "feministas periféricos", em suas conexões, fluxos, tensões e paradoxos. Por fim, também ressalto as conclusões equivocadas acerca dos CDCMs Maria da Penha e Naná Serafim, os quais, como a própria autora explicita, vedaram o seu acesso a estas organizações, não lhe concendo entrevistas (SANTOS, C., 2015 , p. 595); minhas próprias entrevistas com suas coordenadoras contradizem inteiramente a tese levantada pela autora, acerca de uma suposta abordagem "familista" por parte destas duas casas conveniadas, cabendo muito mais falar na adoção de uma perspectiva "de gênero". No caso específico do CDCM Maria da Penha, sua coordenadora em 2015 era filiada ao PCdoB, militante da União Brasileira de Mulheres (UBM) e feminista.

30 Sobre a aposta da Campanha da Lei Maria da Penha no direito penal "como instrumento de resolução de conflito e de mudança social" além de encarar o seu repertório como um "poderoso recurso normativo e instrumental para dar visibilidade pública à temática" da violência contra a mulher, cf. Maciel (2011, p. 97 e 106). 
conscientizando as mulheres que são seu público-alvo acerca de todos os seus direitos, com relação à casa própria, aos filhos, à pensão, etc. Ao abordar a educação sob a perspectiva da educação não formal, ou seja, da construção de uma cultura política democrática (GOHN, 2011), então os CDCMs aparecem como espaços eminentemente educativos.

O surgimento dos CDCMs e sua expansão enquanto serviço privilegiado pela Assistência Social para contribuir na efetivação da Lei Maria da Penha está intimamente conectado com o desenvolvimento do "feminismo popular", uma vez que alguns dos movimentos de mulheres acabaram por desaparecer ao serem canalizados para a execução do convênio ou então outras associações de mulheres que não quiseram ou não puderam se adequar às inevitáveis restrições por parte da SMADS se encontram em uma difícil situação em termos de financiamento e manutenção de sua sede e de atividades contínuas, o que eu gostaria de chamar de uma crise de sustentabilidade prolongada. ${ }^{31}$

\section{O “feminismo periférico”: novos contrapúblicos (fluxos horizontais)}

Nesta seção, apresentarei as duas matrizes discursivas que identifiquei para o "feminismo periférico", em contraste com o momento histórico anterior: no lugar das CEBs (e, em menor medida, da cultura popular do samba e do carnaval), os movimentos culturais periféricos; e no lugar da rede de ONGs feministas com sedes na região centro-oeste de São Paulo, os feminismos dos contrapúblicos digitais.

Se as associações feministas populares surgiram junto ou a partir de movimentos populares urbanos (como as lutas por moradia, saúde e creche), os coletivos feministas periféricos surgiram principalmente no seio de movimentos culturais, como os saraus periféricos e o movimento Hip Hop. O crescente circuito cultural periférico substituiu, de certa maneira, o papel que as CEBs desempenharam nas décadas de 1970 e 80, no sentido de estabelecer

\footnotetext{
$31 \mathrm{O}$ salto de 2 para 7 serviços conveniados na Zona Leste entre 2012-13 aconteceu praticamente ao mesmo tempo da devolução do imóvel da Casa Lilith em 2011, por falta de dinheiro, e da Amzol sendo despejada em 2012 da sua sede em uma Cohab na Vila Mara. Sem suas sedes, estas duas entidades paradigmáticas do "feminismo popular" encontraram muitas dificuldades para seguir atuando. Enquanto a Casa Lilith encerrou suas atividades, a Amzol se candidatou em 2015 para o edital de gestão conveniada do Centro de Referência da Mulher (CRM) em São Miguel. Se em 2016 este convênio salva momentaneamente a Amzol da sua crise de sustentabilidade, um dos primeiros atos do novo prefeito, João Dória (PSDB) é o encerramento abrupto deste contrato logo no início de 2017.
} 
Do "feminismo popular" ao "feminismo periférico" | Jonas Medeiros

uma rede descentralizada de circulação de discursos e formação política, além de propiciar "espaços de convivência formados pelos encontros cotidianos na cidade" (SADER, 1988, p. 118).

Em uma segunda comparação, se o "feminismo popular" teve como principal foco de interlocução com o poder público a assistência social (e outras políticas públicas para efetivar os direitos das mulheres), no caso do "feminismo periférico" a interlocução passou a ser com a política pública cultural. Quando existe algum financiamento estatal de suas atividades (muitas delas são auto-financiadas ou baseadas em trabalho nãoremunerado), ele se dá quase que exclusivamente por meio do Programa VAI, da Secretaria Municipal da Cultura. Estes coletivos feministas não possuem sede própria, costumando ocupar equipamentos públicos estatais (biblioteca municipal, centro cultural, centro educacional) ou não-estatais (biblioteca comunitária, ponto de cultura).

O movimento hip hop e os saraus periféricos podem ser conceitualizados em seu conjunto como um contrapúblico literário (ou artístico-literário), com seus discos, produtoras, gravadoras, livros, editoras independentes e alternativas, zines, eventos, festas, pontos de encontro, sites, blogs, páginas de Facebook, etc. Existe uma quantidade crescente de livros da literatura periférica/marginal e de CDs de rap produzidos por mulheres e, cada vez mais, as autoras, compositoras, leitoras e ouvintes compartilham espaços sociais e referências artísticas, culturais e discursivas, formando um verdadeiro público: o solo a partir do qual emergem os coletivos feministas periféricos.

Contudo, as mulheres continuam sendo minoria neste contrapúblico artístico-literário, não há igualdade nem numérica nem na dinâmica social; mas a realidade está mudando no decorrer da década de 2010. Teresa Caldeira (2014) aponta esta crescente participação feminina na cultura periférica, seja no Hip Hop, seja nos saraus, mas este processo seria marcado por fontes tensões, ambiguidades e contradições, que prenderiam as mulheres seja à "masculinização", seja a uma reivindicação de uma "feminilidade essencializada". Dissertações de mestrado recentes (BALBINO, 2016; RAMOS, 2016) demonstram empiricamente o adensamento da participação feminina nestes movimentos culturais, da mesma forma como meu trabalho de campo. 
No caso do Hip Hop, alguns marcos da presença das mulheres neste movimento são: os Projetos Rappers e Femini Rappers (propostos pelo Geledés na década de 1990), o grupo "Minas da Rima", o portal virtual "Mulheres no Hip Hop" e a Frente Nacional de Mulheres no Hip Hop-FNMH2 (RAMOS, 2016). A pesquisa etnográfica de Ramos disponibiliza elementos que complexificam a relação entre feminismo e mulheres no hip hop para além da dicotomia apontada por Caldeira entre masculinização vs. feminilidade essencializada. De um lado, a inserção das mulheres se dá pela exigência de um frágil equilíbrio "entre ter necessariamente que exibir certa feminilidade, mas sem que esta possa ser lida como muito sensual ou erótica" (RAMOS, 2016, p. 100). A exacerbação da feminilidade pode ser condenada por homens e mulheres (ambos operando em uma oposição entre "mulheres pensantes" e "corpos femininos objetificados", em uma crítica dirigida em parte ao funk) mas a exacerbação da masculinidade passa a ser lida em uma chave homofóbica (embora muito recentemente, rappers feministas e rappers lésbicas têm se expressado artística e politicamente contra e para além destas estruturas machistas e homofóbicas). De outro, as hip hoppers dialogam ativamente entre si e com hip hoppers estrangeiras acerca do feminismo, do "feminismo branco" e do feminismo negro, a partir de uma "demanda de 'periferizar' o feminismo" (RAMOS, 2016, p. 80; meu grifo).

Já no caso dos saraus e da literatura periféricos, um dos seus marcos inaugurais costuma ser identificado no lançamento de edições dedicadas à literatura marginal (organizadas pelo escritor Ferréz e publicadas pela revista Caros Amigos). Nas três edições publicadas entre 2001 e 2004, a participação das mulheres foi "pífia": apenas 16,1\% (BALBINO, 2016, p. 32 e 102). A ausência da equidade de gênero nas coletâneas e antologias da literatura marginal/periférica permanecem por toda a década de 2000, com a situação só mudando quando escritoras periféricas passam a se auto-organizar para publicar coletâneas $100 \%$ compostas por mulheres, como: o livro Águas da Cabaça e as coletâneas Perifeminas I: nossa história, Pretextos de Mulheres Negras e Perifeminas II: sem fronteiras (BALBINO, 2016). A década de 2010 vê uma alteração quantitativa significativa no tocante à divisão de autores por gênero (BALBINO, 2016, p. 109-110): a participação de escritoras superou a dos escritores na passagem de $2013(47,0 \%)$ para 2014 (56,7\%). Além do 
surgimento de coletivos e coletâneas femininos, contribuiu para este novo protagonismo das mulheres a publicação de livros frutos de oficinas de movimentos culturais em escolas públicas; nestes casos, as estudantes sempre foram maioria com relação aos meninos (BALBINO, 2016).

Algumas entrevistas apontaram que o sarau seria um espaço onde se verificaria um machismo menos intenso do que em outras esferas da sociedade. Outras entrevistas contradizem este relato, narrando histórias de preconceito, discriminação e machismo que se acumulam, desvelando relações de poder nas quais os homens ocupam posição privilegiada e opressora. A Cultura Hip Hop é vista como machista, tanto o rap "extremamente dominado por homens", como disse uma das integrantes do Mulheriu Clã - quanto do grafite - militantes do M.A.N.A. Crew relataram já terem sofrido discriminação, tendo seu trabalho desvalorizado e movido para um muro de menor destaque; ou mesmo terem sofrido "olhares abusivos" por partes dos homens, uma situação descrita como desconfortável, incômoda e perturbadora. Sofrer situações de violência machista culminam em decisões de mulheres de saírem de coletivos mistos e buscarem auto-organizações apenas de mulheres. Depois de alguns meses da primeira entrevista que eu realizei, um dos coletivos rompeu com o sarau periférico do qual era o seu núcleo feminista, por conta de vários episódios sexistas envolvendo um poeta.

A presença crescente de mulheres nestes movimentos culturais permitiu uma solidariedade que fortalece e retroalimenta a ocupação feminina de cada vez mais espaços, com coletivos já consolidados abrindo portas para as mais jovens e menos articuladas, seja indicando caminhos de financiamento de projetos culturais via editais, seja apoiando organizacional e emocionalmente as que chegam na cena cultural mais tardiamente, seja inspirando a adoção de repertórios até então desconhecidos ou inconcebíveis, a partir do seu exemplo cotidiano.

Estes movimentos culturais periféricos são certamente o espaço de sociabilidade mais relevante para a gênese dos coletivos feministas aqui analisados, a principal base de formação e solo a partir do qual eles emergem. É principalmente nestes movimentos artístico-culturais que se desenvolve hoje aquela sociabilidade básica, densa e significativa da qual falava Magnani 
(2003, p. 113), a "intrincada rede de relações" a partir da qual se atribuem identidades às diferentes quebradas - categoria nativa que hoje atualiza aquela antiga noção de "pedaço" (MAGNANI apud SADER, 1988, p. 120-121). Contudo, verifiquei fluxos horizontais em direção a (sub)contrapúblicos feministas no interior deste contrapúblico literário periférico devido ao machismo que o estrutura. Neste sentido, a articulação entre classe e raça expressa pela categoria nativa "periférico" é enriquecida pelo marcador social do gênero, resultando na generificação do que D'Andrea (2013) chamou de "sujeito periférico", em direção à noção de mulheres periféricas.

A segunda matriz discursiva do "feminismo periférico" são os feminismos dos contrapúblicos digitais. Enquanto o "feminismo popular" foi marcado pela mediação de uma assessoria técnica feminista "externa" (no formato de ONGs com sedes fora da Zona Leste), uma característica deste novo momento histórico é o papel crucial que a internet agora desempenha para democratizar o acesso direto e imediato à produção, circulação e recepção de debates e textos feministas. Nas entrevistas, as jovens ativistas apontaram a internet como um tópico relevante, como neste caso de uma integrante do coletivo Juntas na Luta:

[...] esse boom do feminismo periférico, sabe? Da mulher aprender sobre transfobia no grupo de debate do Facebook, independente se ela já pisou numa universidade ou não. Também acho que isso é um avanço, sabe? O fato do tema tá sendo discutido mais largamente, sabe? Isso foi resultado do movimento feminista.

A bibliografia sobre "feminismo digital", "ciberfeminismo" ou "feminismo comunicacional" (VALENTE; NERIS, 2018) ainda é pouco sistematizada. Alguns objetos são inclusive muito mais visados (como as diferentes Marchas das Vadias ou o "Blogueiras Feministas") e outras problemáticas de pesquisa - como o caso dos blogs, páginas de Facebook, canais do Youtube e outros espaços virtuais centrais para o feminismo negro - recebem menos atenção dos e das investigadoras.

Uma exceção é o mestrado de Modelli (2016), que compara o Blogueiras Feministas e o Blogueiras Negras, blogs por ela interpretados como "espaços de conversação". A autora aponta que a internet possui um caráter ambiguo: por um lado, pode reforçar desigualdades e violências de gênero; por outro, constitui um novo "espaço comunicacional" que potencializa novas ações 
Do "feminismo popular" ao "feminismo periférico" | Jonas Medeiros

coletivas feministas em oposição aos silenciamentos e estereótipos típicos da grande mídia tradicional. Os feminismos dos contrapúblicos digitais podem ser interpretados como uma matriz discursiva do "feminismo periférico" a partir do modo como o compartilhamento de narrativas pessoais auxilia na construção de uma identidade coletiva (MODELLI, 2016, p. 87). Partilhar "histórias autobiográficas" é uma ação que permite reelaborar simbolicamente a vida cotidiana e o reconhecimento de padrões de opressão, dominação e exploração contra os quais é possível lutar, em vez de vivências que se apresentam como isoladas, localizadas e puramente individualizadas, o que tende a esconder os processos sociais que produzem tais situações. Além disso, as redes sociais digitais permitem ampliar exponencialmente a sociabilidade das jovens: a internet é espaço de encontro, de início de amizades que viabilizam a fundação de coletivos, o que Castells (2015) chama de "individualismo conectado".32

Tendo isto em vista, realizei uma análise quantitativa da rede de páginas do Facebook seguidas pelas ativistas dos coletivos que eu entrevistei. Depois de mapear as páginas "curtidas" relativas a debates feministas e dos direitos das mulheres, listei, no final de julho de 2016, 828 páginas a partir de 24 perfis pessoais de militantes (pertencentes a sete coletivos). O grau de diversidade, heterogeneidade e fragmentação do processo de formação da opinião nos contrapúblicos digitais é surpreendente. Foi comum perceber que páginas que poderiam ser do interesse de várias ativistas tinham a "curtida" de apenas uma delas, revelando o caráter extremamente descentralizado das discussões na internet. A análise de rede (por meio da aplicação de um algoritmo pelo software Gephi) 33 identificou cinco clusters (“agrupamentos"), os quais podem ser interpretados como constituindo públicos de leitores

\footnotetext{
32 Segundo o mesmo Castells, com o desenvolvimento da Web 2.0, surge uma nova forma de comunicação, que ele chama de autocomunicação de massa, caracterizada por três elementos: (1) alcança uma audiência potencialmente global; (2) é multimodal pois a digitalização permite a reformatação de diversos conteúdos em formas variadas; e (3) congrega "conteúdo autogerado, emissão autodirecionada e recepção autosselecionada por muitos que se comunicam com muitos" (CASTELLS, 2015 , p. 118). As práticas verticais de comunicação não seriam anuladas, mas haveria ao mesmo tempo complementariedade e conflitos com redes horizontais. Conforme os sujeitos passam a ser simultaneamente emissores e receptores de mensagens, a internet fortaleceria "práticas de autonomia" (CASTELLS, 2015, p. 183). As mensagens passam a ser interpretadas em um processo amplamente dinâmico, com a produção de significado sendo interativa, o que constitui uma "audiência criativa" (CASTELLS, 2015, p. 184).

33 Agradeço à assistência técnica de Márcio Moretto Ribeiro, sem a qual esta análise não teria sido possivel. O procedimento está explicado com mais detalhes na seção 3.2.2 de minha tese (MEDEIROS, 2017, p. 136-137).
} 
comuns, envolvendo todas as pessoas que seguem estas páginas de Facebook (e não apenas as militantes dos coletivos com quem tenho "amizade" nesta rede social). Ou seja, o material empírico analisado e interpretado indicou, simplificadamente, a existência de cinco contrapúblicos digitais distintos (tal como é possivel visualizar na imagem abaixo, junto com os nomes das seis páginas mais "seguidas" de cada agrupamento): [1] o feminismo digital, composto por várias páginas de Facebook e blogs sem existência física ou material organizada fora da realidade virtual (em vermelho); [2] os movimentos culturais periféricos (em rosa); [3] o sagrado feminino (em laranja); [4] o feminismo institucional, como ONGs, movimentos sociais tradicionais, feminismo estatal e organismos internacionais (em azul); e, por fim, [5] mulheres negras e feminismo negro (em verde). ${ }^{34}$

Imagem 1 - Agrupamentos da rede de páginas do Facebook

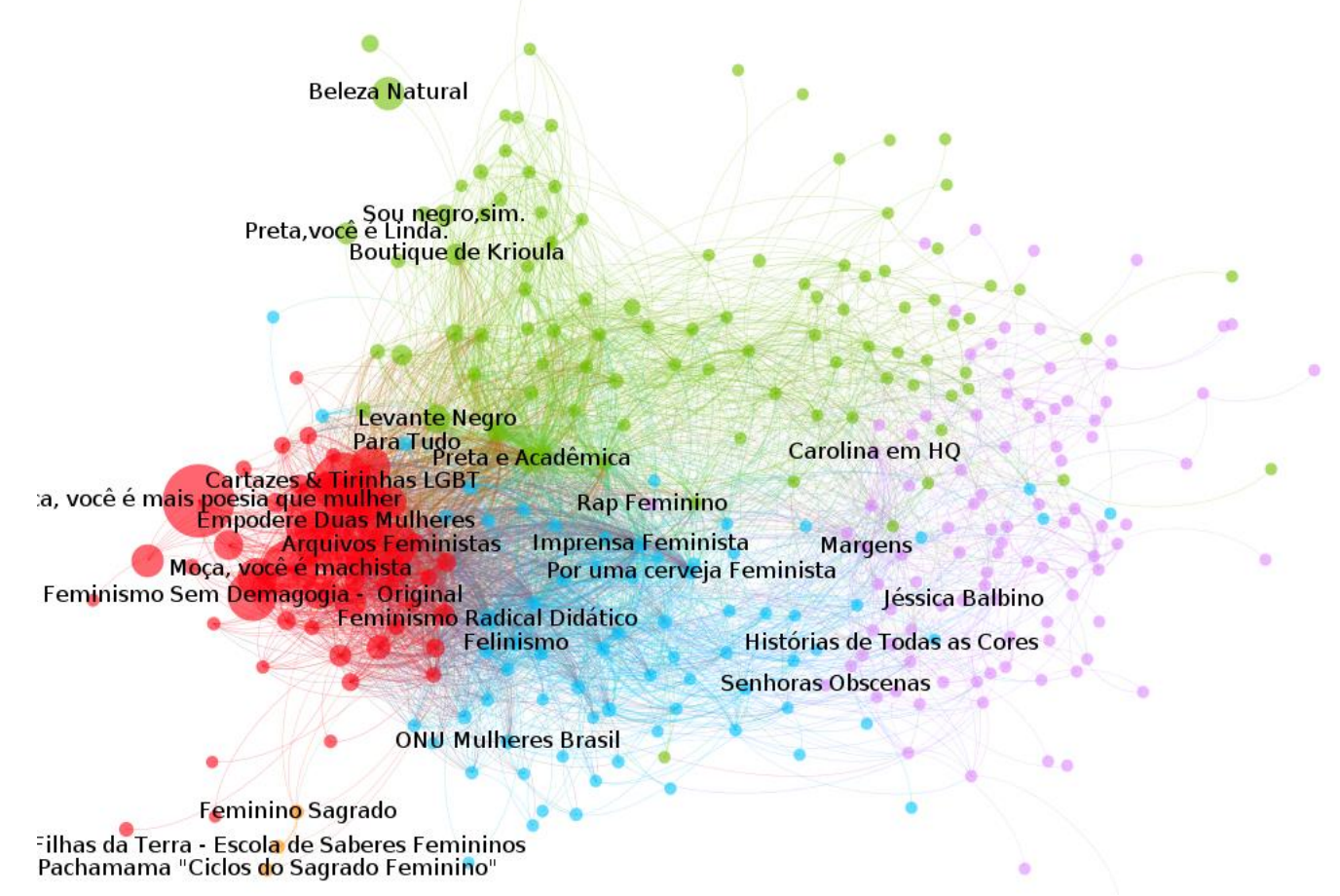

Fonte: elaboração por Márcio Moretto Ribeiro a pedido do autor.

\footnotetext{
34 É possível visualizar o modo como cada agrupamento está estruturado em diversos subagrupamentos - ou seja: públicos e subpúblicos - em Medeiros (2017, p. 139-146).
} 
Do "feminismo popular" ao "feminismo periférico" | Jonas Medeiros

Um dos clusters mais importantes para o "feminismo periférico" é este último, das mulheres negras, o que nos ajuda a compreender como e porque a questão racial ganhou centralidade no ativismo destas mulheres jovens (MEDEIROS, 2017, p. 167-193). Esta matriz discursiva é, contudo, complexa e precisa ser apreendida com nuances. Em primeiro lugar, não é possivel entendê-la apenas por uma via teórico-conceitual (páginas como Blogueiras Negras, Sueli Carneiro e Lélia Gonzalez) mas é necessário também explorar a contribuição de uma via estético-expressiva, por assim dizer: todas as páginas dedicadas às temáticas da beleza da mulher negra, como um meio de combater a intersecção entre racismo e machismo, por meio da valorização da sua identidade, sua estética e sua autoestima. Em segundo lugar, mesmo em termos de vertentes teóricas, não há uma unidade necessária: convivem no interior do "feminismo periférico" enquadramentos diversos, nomeadamente o feminismo negro (muitas vezes o termo feminismo interseccional é utilizado como seu sinônimo) e o mulherismo africana (MEDEIROS, 2017, p. 149 e 190193).

A recepção e a apropriação das teorias feministas deixaram, portanto, de se dar por meio de agências de mediação e passaram a ser realizadas de forma autônoma pelas militantes e ativistas periféricas, de modo "individuado" (CASTELLS, 2013, p. 172) e bastante fragmentado: nem mesmo no interior de cada coletivo é possivel dizer que a apropriação dos feminismos se dê de forma homogênea - cada timeline do Facebook é singular.

\section{Considerações finais: mudanças estruturais em contrapúblicos}

Em minha pesquisa, detectei descontinuidades entre os momentos históricos do associativismo de mulheres da Zona Leste, quando considerada uma dimensão que pode ser chamada de societal, isto é: experiências socializadoras, formas de sociabilidade e matrizes discursivas enquanto contrapúblicos subalternos. Gostaria de nomear, nesta conclusão, estas descontinuidades como cinco mudanças estruturais nos contrapúblicos deste território:

[i] Os CDCMs (criados entre 2002-13) institucionalizaram a prática inaugurada nos anos 1990 pelo "feminismo popular" de atendimento psicológico e jurídico a mulheres em situação de violência como parte da 
assistência social municipal. As entidades que foram pioneiras neste tipo de atendimento se viram crescentemente constrangidas a adotar este formato dos convênios pois entraram em uma prolongada crise de sustentabilidade financeira, praticamente ao mesmo tempo que em que se consolida, muito recentemente, a Rede Leste de Enfrentamento à Violência, com suas casas conveniadas passando a atender mulheres em seu lugar. Alvarez (2014a) chamou este processo de institucionalização no qual militantes feministas passam a gerir serviços públicos de "fluxos verticais" (da sociedade civil em direção à sociedade política). A autora também trabalha com outro conceito útil para interpretar esta situação, o de "paradoxo transformador": a institucionalização de uma prática do movimento feminista sob a forma de uma política pública municipal de assistência social, ao alterar estruturalmente o ambiente político-institucional do associativismo de mulheres na Zona Leste, abriu espaço paradoxalmente para práticas menos institucionalizadas, como as práticas artístico-culturais dos coletivos feministas periféricos, uma vez que o atendimento de mulheres em situação de violência não precisa mais ser um encargo direto da auto-organização das mulheres, pois passou a existir uma rede de serviços que realiza cotidianamente esta prática. Contribuíram também para o impulso de institucionalização das associações feministas populares (sua transformação de contra públicos para públicos fortes, nos sentidos dados por Fraser), a restrição aguda do seu financiamento externo (ONGs cristãs internacionais como as holandesas ICCO e Fundação Samuel e a alemã Misereor deixaram de priorizar projetos no Brasil a partir do governo Lula) e algumas alterações institucionais internas (como a promulgação da Lei Maria da Penha e a criação da Defensoria Pública do Estado de São Paulo, ambas em 2006).

[ii] As ONG's feministas da região centro-oeste da capital paulista se afastaram do trabalho de base na Zona Leste e deixaram de atuar na assessoria técnica para o "feminismo popular". Emblemático disso é a saída da SOF de São Miguel Paulista, em torno de 1996-97, quando deixa sua sede para focar sua atuação na Zona Sul de São Paulo. Este fato é lembrado em algumas entrevistas como algo de consequências profundas, como pude também presenciar na fala de uma das militantes entrevistadas em uma das Plenárias Deliberativas promovidas pela Secretaria Municipal de Políticas para 
Do "feminismo popular" ao "feminismo periférico" | Jonas Medeiros

Mulheres no início do ano de 2015, com assessoria da SOF. Ela exaltou a possibilidade de retomar naquele momento o trabalho das décadas de 1980 e 90 pois com a saída da SOF “nós não conseguimos nos segurar": "é pouca mulher para muita atividade"; seu maior desejo era "que as mulheres voltem a se reunir como antes"; vários trabalhos com as mulheres haviam sido feitos com a SOF na região, mas quando ela "foi só para a Zona Sul, nosso trabalho caiu". A mediação teórica acerca de gênero e feminismo propiciada por esta rede organizacional externa foi substituída pelo acesso imediato (no sentido de não mais mediado por aquelas ONGs ou outras instituições) a discursos, teorias e debates feministas propiciado pelas redes sociais digitais. Processos subjacentes a este fenômeno foram chamados de “digitalização das esferas públicas” (CELIKATES, 2015) e de “autocomunicação de massa” (CASTELLS, 2015): uma revolução tecnológica na base material das formas de comunicação, que possibilitou a produção, a circulação e a recepção de discursos de modo horizontal, extremamente descentralizado e potencialmente transnacional, fomentando uma "audiência criativa" e uma "cultura da autonomia", nas quais a formação e a informação - no caso de minha pesquisa empírica, de discursos feministas - passa a ocorrer de maneira imediata (isto é, sem mediadores), heterogênea e singular. A segunda mudança estrutural foi, portanto, a substituição daquela rede articuladora de ONGs feministas com sedes fora da Zona Leste por contrapúblicos digitais.

[iii] Se no "feminismo popular" o Partido dos Trabalhadores era um "nó articulador" (ALVAREZ, 2014a, p. 27-28), o "feminismo periférico" é constituído por coletivos (auto-organizações horizontais) de caráter apartidário. O enraizamento do PT na vida cotidiana das periferias urbanas era garantido pelo trabalho de base, facilitado por certas organizações e movimentos populares urbanos. Mesmo que os coletivos feministas periféricos e suas integrantes possam eventualmente se beneficiar de politicas públicas oriundas de governos petistas (como o Programa VAI no nível municipal e o ProUni no nível federal), o PT não lhes propiciou espaços de sociabilidade tal como ocorreu para o "feminismo popular". Todas as entrevistadas pelas associações feministas populares fizeram parte do partido em algum momento de suas trajetórias militantes. Em meados da década de 1990, a prioridade do 
partido deixa de ser a construção "de baixo para cima", a partir dos movimentos sociais e das bases populares, para se concentrar mais na disputa da eleição presidencial; esta estratégia, aliada a uma saída de lideranças de suas bases para trabalhar em gabinetes, resulta em um processo que muitos autores qualificam como uma "burocratização" do partido. ${ }^{35}$ Algumas entrevistadas, mesmo permanecendo filiadas ao PT, demonstram alguma decepção com os rumos do partido; mesmo que publicamente defendam-no e ao governo da então presidenta Dilma Rousseff (inclusive de modo enfático nas redes sociais), reservadamente, com o microfone ligado ou não, compartilham sua infelicidade e sua dificuldade em serem cabos eleitorais em suas regiões de atuação, por conta seja do governo federal (da então presidente Dilma Rousseff), seja do municipal (a gestão do então prefeito Fernando Haddad). De qualquer modo, o mais importante a ser destacado é a ausência de trabalho de base por parte do PT, o que tem consequências diretas para as atividades das associações, organizações e movimentos que gravitavam em torno dele desde a década de 1980, alterando estruturalmente as possibilidades das classes populares entrarem na cena pública por meio do sistema partidário.

[iv] As CEB's foram praticamente anuladas enquanto contrapúblicos subalternos enraizados no cotidiano das periferias urbanas por meio de dois processos. Em primeiro lugar, há de se considerar os efeitos profundos e demorados da intervenção do Vaticano na Igreja Católica paulistana a partir de 1989, com o desmembramento da Arquidiocese de São Paulo e a criação da Diocese de São Miguel Paulista, substituindo Dom Angélico Sândalo Bernardino, religioso progressista e auxiliar de Dom Paulo Evaristo Arns, por um bispo conservador. A mudança no topo da hierarquia da região leste tem consequências até o cotidiano local e microscópico, com mudanças de padres nas paróquias, alterações na liturgia que reinstauram o distanciamento entre clero e laicato, sem contar os obstáculos levantados a iniciativas antes consideradas normais e mesmo desejáveis (como impedir a utilização do salão da paróquia para a realização de reuniões, seja dos movimentos populares,

\footnotetext{
35 Secco (2011), por exemplo, analisa a história do PT mostrando como no seu início ele atuava como "oposição social" (extraparlamentar), mas na década de 1990 ele passa a agir como "oposição parlamentar", até que, após a eleição de Lula em 2002, passa a ser "partido de governo". Para uma outra análise desta estratégia eleitoral do PT e da sua aceitação crescente da lógica de funcionamento do sistema político brasileiro, cf. Nobre (2013).
} 
seja dos grupos de mulheres em nome de atividades mais diretamente religiosas) e até perseguições diretas e inescrupulosas a certos membros da comunidade envolvidos em atividades políticas. Esta intervenção política conservadora, com consequências nas vivências politicas, espirituais e cotidianas das feministas populares, se aliou a um segundo processo, amplo (e irreversível), de diversificação do campo religioso local, metropolitano e nacional, sendo que esta pluralização religiosa foi ainda mais intensa na Zona Leste do que em outras regiões da cidade, principalmente em termos do crescimento de igrejas pentecostais e neopentecostais. Isto corroeu ainda mais os fundamentos que antes facilitavam enormemente tanto um diálogo entre lideranças e bases no interior do "feminismo popular" por meio da Teologia da Libertação - como também permitiam que o espaço eclesial fosse muito mais do que isso, enquanto espaço de encontro, lazer e rede de sociabilidade - na forma das CEBs (MACEDO, 1986). Assim, a religiosidade deixou de ser um espaço de sociabilidade estruturante da gênese do novo associativismo de mulheres, deixando de se constituir como uma das suas matrizes discursivas. Friso, contudo, que é equivocado pressupor que determinadas experiências religiosas sejam intrinsecamente bloqueadoras de ações coletivas em prol dos direitos das mulheres, como pude atestar a partir da origem evangélica de várias das jovens entrevistadas.

[v] A última mudança estrutural que quero apontar é o adensamento dos contrapúblicos negros na década de 2010. Ambas as matrizes discursivas do "feminismo periférico" (o contrapúblico artístico-literário da cultura periférica e o contrapúblico digital em torno do feminismo negro, do mulherismo africana, sem contar todas as páginas, sites, blogs e canais do Youtube dedicados à estética e à beleza das mulheres negras) podem ser conceitualizadas como esferas públicas negras enquanto que no caso do "feminismo popular", apenas a sua terceira e minoritária matriz discursiva (as escolas de samba e os blocos afro) poderia ser assim compreendida. A centralidade da questão racial para as jovens ativistas das periferias da Zona Leste (não apenas no caso das mulheres periféricas negras como também das brancas) pode ser interpretada como resultado da emergência e o adensamento destes novos contrapúblicos negros, o que possibilitou a circulação de um código oposicional antirracista de um modo muito mais 
intenso neste segundo momento histórico do que no primeiro. Se o feminismo negro já era presente e atuante no "feminismo popular", porém de modo minoritário, ele passa, no "feminismo periférico", da margem para o centro, constituindo a sua referência discursiva majoritária.

\section{Referências}

ABERS, Rebecca \& TATAGIBA, Luciana. Institutional Activism: Mobilizing for Women's Health from Inside Brazilian Bureaucracy. In: ROSSI, Frederico M. \& BÜLLOW, Marisa von. Social Movement Dynamics: New Perspectives on Theory and Research from Latin America. London/New York: Routledge, 2015.

ALVAREZ, Sonia. Latin American Feminisms "Go Global": Trends of the 90s and Challenges for the New Millenium. In: ALVAREZ, Sonia, DAGNINO, Evelina \& ESCOBAR, Arturo. The Cultures of Politics and the Politics of Culture: Re-visioning Social Movements in Latin America. Boulder: Westview, 1998.

ALVAREZ, Sonia. Para além da sociedade civil: reflexões sobre o campo feminista. Cadernos Pagu, Campinas, n. 43, 2014a.

ALVAREZ, Sonia. Engajamentos ambivalentes, efeitos paradoxais? Movimentos feminista e de mulheres na América Latina e/em/contra o desenvolvimento. Revista Feminismos, Salvador, v. 2, n. 1, 2014b.

BALBINO, Jéssica. Pelas Margens: vozes femininas na literatura periférica. Dissertação (Mestrado em Divulgação Científica e Cultural) - Instituto de Estudos da Linguagem, Universidade Estadual de Campinas, Campinas, 2016.

BERGER, Peter \& LUCKMANN, Thomas. A construção social da realidade. Petrópolis: Vozes, 1983.

CALDEIRA, Teresa. Gênero continua a ser o campo de batalhas: juventude, produção cultural e a reinvenção do espaço público em São Paulo. Revista USP, São Paulo, n. 102, 2014.

CARLOS, Elza da Silva. Fala Preta! Mulheres negras no espaço urbano: origem e memória - 1997 a 2007. Dissertação (Mestrado em História Social) Pontifícia Universidade Católica de São Paulo, São Paulo, 2009.

CASTELLS, Manuel. Redes de indignação e esperança: movimentos sociais na era da internet. Rio de Janeiro: Zahar, 2013.

CASTELLS, Manuel. O poder da comunicação. Rio de Janeiro/São Paulo: Paz e Terra, 2015.

CASTRO, Márcio Sampaio. Bexiga: um bairro afro-italiano. São Paulo: Annablume, 2008. 
Do "feminismo popular" ao "feminismo periférico" | Jonas Medeiros

CELIKATES, Robin. Digital Publics, Digital Contestation: a New Structural Transformation of the Public Sphere? In: CELIKATES, Robin, KREIDE, Regina $\&$ WESCHE, Tilo. Transformations of Democracy. Londres: Rowman \& Littlefield, 2015.

COLETIVO FEMINISTA SEXUALIDADE E SAÚDE. Saúde das mulheres: experiência e prática do coletivo feminista sexualidade e saúde. São Paulo, 2000.

CORREIA, Ana Paula de Santana. Mulheres da periferia em movimento: um estudo sobre outras trajetórias do feminismo. Dissertação (Mestrado em Ciências Sociais) - Escola de Filosofia, Letras e Ciências Humanas, Universidade Federal de São Paulo, Guarulhos, 2015.

D'ANDREA, Tiaraju Pablo. A formação dos sujeitos periféricos: cultura e política na periferia de São Paulo. Tese (Doutorado em Sociologia) - Faculdade de Filosofia, Letras e Ciências Humanas, Universidade de São Paulo, São Paulo, 2013.

FANTI, Fabiola. Mobilização social e luta por direitos: um estudo sobre o movimento feminista. Tese (Doutorado em Ciências Sociais) - Instituto de Filosofia e Ciências Humanas, Universidade Estadual de Campinas, Campinas, 2016.

FELTRAN, Gabriel. Desvelar a politica na periferia: histórias de movimentos sociais em São Paulo. São Paulo: Humanitas/Fapesp, 2005.

FRASER, Nancy. Rethinking the Public Sphere: A Contribution to the Critique of Actually Existing Democracy. In: CALHOUN, Craig. Habermas and the Public Sphere. Cambridge/London: The MIT Press, 1992.

GOHN, Maria da Glória. Educação não formal e cultura politica: impactos sobre o associativismo do terceiro setor. São Paulo: Cortez, 2011.

GOMIDE, Denise. Mulheres na coordenação de organizações do terceiro setor no municipio de São Paulo (1990-2000): construção de sujeitos coletivos e de propostas socioeducativas. Dissertação (Mestrado em Educação) - Faculdade de Educação, Universidade Estadual de Campinas, Campinas, 2002.

HABERMAS, Jürgen. Mudança estrutural da esfera pública. São Paulo: Unesp, 2014.

HALL, Stuart. Encoding, Decoding. In: DURING, Simon. The Cultural Studies Reader. 2nd ed. London/New York: Routledge, 1999.

HALL, Stuart. Reflexões sobre o modelo de codificação/decodificação: uma entrevista com Stuart Hall. In: HALL, Stuart. Da diáspora: identidades e mediações culturais. Belo Horizonte/Brasilia: UFMG/Unesco, 2003.

HANCHARD, Michael. Black Cinderella?: Race and the Public Sphere in Brazil. Public Culture, v. 7, n. 1, 1994. 
IFFLY, Catherine. Transformar a metrópole: Igreja Católica, territórios e mobilizações sociais em São Paulo, 1970-2000. São Paulo: UNESP, 2010.

LADEIRA, Thatiane Coghi. Sexualidade e ruptura de vínculos familiares: a importância do serviço social na atenção às mulheres em situação de violência. In: FAZENDO GENERO, 10., 2013, Florianópolis. Anais... Florianópolis: UFSC, 2013.

LORENZO, Rocío Alonso. Agindo como Promotora Legal Popular: uma abordagem das "interseções" e da etnografia da fala. In: ENCONTRO ANUAL DA ANPOCS, 36., Águas de Lindoia. Anais... Águas de Lindoia: ANPOCS, 2012.

MACEDO, Carmen Cinira. Tempo de gênesis: o povo das comunidades eclesiais de base. São Paulo: Brasiliense, 1986.

MACIEL, Débora Alves. Ação coletiva, mobilização do direito e instituições politicas: o caso da campanha da lei Maria da Penha. Revista Brasileira de Ciências Sociais, São Paulo, v. 26, n. 77, 2011.

MAGNANI, José Guilherme Cantor. Festa no pedaço: cultura popular e lazer na cidade. $3^{a}$ ed. São Paulo: Hucitec/Unesp, 2003.

MARTINS, Shirlei Cristina de Fátima. Violência doméstica contra a mulher: quando o filho é o agente da agressão. Monografia (Especialização em Psicopatologia e Saúde Mental) - Faculdade de Saúde Pública, Universidade de São Paulo, São Paulo, 2015.

MEDEIROS, Jonas. Movimentos de mulheres periféricas na Zona Leste de São Paulo: ciclos políticos, redes discursivas e contrapúblicos. Tese (Doutorado em Educação) - Faculdade de Educação, Universidade Estadual de Campinas, Campinas, 2017.

MEDEIROS, Jonas. Conhecimento situado, gênero e raça: uma experiência de campo na Zona Leste de São Paulo. Revista Plural, São Paulo, v. 26, n. 1, 2019.

MEDEIROS, Jonas \& FANTI, Fabiola. Recent Changes in the Brazilian Feminist Movement: The Emergence of New Collective Subjects. In: FERRERO, Juan Pablo, TATAGIBA, Luciana \& NATALUCCI, Ana. Socio-Political Dynamics within the Crisis of the Left Turn: Argentina and Brazil. Londres: Rowman \& Littlefield, 2019.

MENDONÇA, Luciana Ferreira Moura. As Mulheres Negras do Oriashé: música e negritude no contexto urbano. Cadernos de Campo, São Paulo, n. 3, 1993.

MODELLI, Laís. Blogs coletivos feministas: um estudo sobre o feminismo brasileiro na era das redes sociais na internet. Dissertação (Mestrado em Comunicação) - Faculdade de Arquitetura, Artes e Comunicação, Universidade Estadual Paulista, Bauru, 2016. 
Do "feminismo popular" ao "feminismo periférico" | Jonas Medeiros

NOBRE, Marcos. Imobilismo em movimento: da abertura democrática ao governo Dilma. São Paulo: Companhia das Letras, 2013.

OLIVEIRA, Júlia Glaciela da Silva. União de Mulheres de São Paulo: feminismo, violência de gênero e subjetividades. Dissertação (Mestrado em História) - Instituto de Filosofia e Ciências Humanas, Universidade Estadual de Campinas, Campinas, 2013.

OLIVEIRA, Kelly Adriano. Entre o lúdico e a luta: Leandro de Itaquera, uma escola de samba na cidade de São Paulo. Dissertação (Mestrado em Antropologia Social) - Faculdade de Filosofia, Letras e Ciências Humanas, Universidade de São Paulo, São Paulo, 2002.

PINTO, Christiane Soares. Sobre violências vivenciadas por mulheres, suas marcas e significados. Dissertação (Mestrado em Saúde Pública) - Faculdade de Saúde Pública, Universidade de São Paulo, São Paulo, 2016.

RAMOS, Izabela Nalio. Entre "perifeminas" e "minas de artilharia": participação e identidade de mulheres no hip hop e no funk. Dissertação (Mestrado em Antropologia) - Faculdade de Filosofia, Letras e Ciências Humanas, Universidade de São Paulo, São Paulo, 2016.

RICOLDI, Arlene Martinez. A experiência das promotoras legais populares em São Paulo: gênero e cidadania. Dissertação (Mestrado em Sociologia) Faculdade de Filosofia, Letras e Ciências Humanas, Universidade de São Paulo, São Paulo, 2005.

SADER, Éder. Quando novos personagens entraram em cena: experiências, falas e lutas dos trabalhadores da Grande São Paulo (1970-80). Rio de Janeiro: Paz e Terra, 1988.

SANTOS, Cecília MacDowell. Curto-circuito, falta de linha ou na linha? Redes de enfrentamento à violência contra mulheres em São Paulo. Revista Estudos Feministas, Florianópolis, v. 23, n. 2, 2015.

SANTOS, Sônia Beatriz dos. Brazilian Black Women's NGOs and Their Struggles in the Area of Sexual and Reproductive Health: Experiences, Resistance, and Politics. Tese (Doutorado em Antropologia) - University of Texas, Austin, 2008.

SECCO, Lincoln. A história do PT. Cotia: Ateliê Editorial, 2011.

SILVA, Renata Carvalho da. História da Casa Viviane. 4 pp., 2014.

SOUZA, Bruna Mantese de. Mulheres de fibra: narrativas e o ato de narrar entre usuárias e profissionais de um serviço de atenção a vítimas de violência na periferia de São Paulo. Tese (Doutorado em Ciências Sociais) - Instituto de Filosofia e Ciências Humanas, Universidade Estadual de Campinas, Campinas, 2015.

SOUZA, Valéria Alves de. Os tambores das "yabás": raça, sexualidade, gênero e cultura no Bloco Afro Ilú Obá De Min. Dissertação (Mestrado em 
Antropologia) - Faculdade de Filosofia, Letras e Ciências Humanas, Universidade de São Paulo, São Paulo, 2014.

SOUZA, Juciara Almeida, MACEDO, Karla Paula Del Rei \& FERNANDES, Miralva Silva. Atuação das Promotoras Legais Populares no Hospital Geral de São Mateus: um serviço de proteção de defesa do direito da mulher. Trabalho de Conclusão de Curso (Graduação em Serviço Social) Universidade Camilo Castelo Branco, São Paulo, 2014.

TOMITA, Luiza Etsuko. Corpo e Cotidiano: a experiência de mulheres de movimentos populares desafia a Teologia Feminista da Libertação na América Latina. Tese (Doutorado em Ciências da Religião) - Universidade Metodista de São Paulo, São Bernardo do Campo, 2004.

VALENTE, Mariana; NERIS, Natália. Elas vão feminizar a internet? O papel e o impacto do ativismo online para os feminismos no Brasil. Sur: Revista Internacional de Direitos Humanos, v. 15, n. 27, 2018.

VIEZZER, Moema. O problema não está na mulher. São Paulo: Cortez, 1989. 